\title{
Internal Migration Determinants: Evidence from Northern Region of Ghana
}

\author{
Abdul-Malik Abdulai \\ University for Development Studies, Department of Mathematics, Navrongo, UER \\ malikbanmibebu@yahoo.com \\ DOI//http://dx.doi.org/10.4314/gjds.v13i1.1
}

\begin{abstract}
Studies of migration in Ghana - exploring the determinants is not new and date back to the 1960s. However, recent empirical evidence has focused on analysing the determinants of international migration. The study of internal migration have been somewhat neglected when in fact, it constitutes a very important policy area. Apart from the existence of very few empirical studies exploring the determinants of migration using econometric approach, results from such studies give mixed findings. The current study adds to the Ghanaian literature by offering a novel empirical assessment of the socio-economic characteristics of Ghanaian migrants and the determinants of internal migration using a recently collected data by the Centre for Migration Studies, University of Ghana, Legon for analysis. The main reason cited for migrating from the Northern region is economic. Using probit regression, it was noted that migrants are more likely to come from households with male heads. Furthermore, access to community facilities (electricity, pipe-born water) reduces the likelihood of households producing migrants. Migrant networks were also found to be a key facilitating element in the migration of people from the study area. In light of this, one can therefore conclude that the network theory explains migration in the Northern Region.
\end{abstract}

Keywords: Internal Migration, Determinants, Migrant, Northern Region, Network

\section{Introduction}

Internal migration mostly composed of young adults and the poor constitute the largest flow of people in developing countries (UNDP, 2009). Internal migration in our context comprises people moving from their place of origin to destination by crossing a well-defined geographical boundary within Ghana. This movement of people could be inter-district or inter-regional. Recent empirical evidence has focused on analysing the determinants as well as the impact of international migration. The study of internal migration has been somewhat neglected when in fact, it constitute a very important policy area. For instance, it is estimated that 98.7 percent of all migrants in Ghana are internal migrants (Ghana Statistical Service, 2012). The lack of such studies may be partly due to the lack of reliable data as well as the fact that internal migration is far less of a political issue (Herrera \& Sahn, 2013). 
Early studies by Beals et al. (1976) and Caldwell (1968) found a negative effect of area of origin's income on rural-urban migration (Beals et al., 1976), but a positive effect of a household's own income on the probability to migrate (Caldwell, 1968). Other important determinants of migration noted by Caldwell include the presence of migration network, gender, age, with younger persons more likely to migrate and household size, with larger households producing a greater number of migrants.

Apart from the existence of very few empirical studies exploring the determinants of migration using econometric approach (see Ackah \& Medvedev, 2010; Boakye-Yiadom \& McKay, 2006 and Waddington \& Lichfield, 2003), results from such studies gives mixed findings . Using data from the Ghana Living Standard Survey round 5 (GLSS 5), Ackah and Medvedev (2010) noted that person's age, civil status and educational attainment are important determinants of migration decisions, while gender is not. Similarly, BoakyeYiadom and McKay (2006) found marital status and education as significant determinants of urban to rural migration, with higher educational attainment reducing the probability of migrating. Having acknowledged the remarkable contribution of these studies to the migration literature in Ghana, it is not devoid of criticism. Apart from the fact that dataset used by these studies are obsolete, census datasets are normally multi-purpose and therefore might not contain comprehensive/detailed migration data to enable one to sufficiently deal with determinants of internal migration and therefore more needs to be known on this subject.

\section{Objectives of the Study}

This paper adds to the Ghana migration literature as summarized above by:

(i) Assessing the socio-economic characteristics of Ghanaian migrants.

(ii) Examining the determinants of internal migration from the study area.

\section{Methodology of the Study}

Data used for this study was sourced from the Migrating Out of Poverty (MOP) dataset collected by the Centre for Migration Studies, University of Ghana in collaboration with the Sussex University, U.K from March to May, 2013. This dataset is unique1 over the census datasets which are predominantly used by most studies in Ghana. A multi-stage sampling technique was used to select 315 households in the Northern Region, consisting of 231 migrant and 84 non-migrant households for interview. The first stage was a purposive selection of 11 districts consisting of 21 Enumeration Areas (EAs) selected from a list of EAs in the 2010 National Population Census results. The number of EAs selected from each district is proportional to the total number of out-migrants from that district. These districts are

1 Given that the survey was specifically designed for migrant source regions with high incidence of poverty was more detailed and comprehensive. 
the Tolon, Savelugu-Nantong, Kumbungu, Sagnarigu, Central and East Gonja, West and East Mamprusi, Kariga, Yendi Municipality and Tamale Metropolis. The selection of these districts was informed by the high proportion of out-migrants produced by those districts using the 2010 National Population Census results. This was followed by a listing of households in these selected EAs. The second stage involved a systematic sampling with a random start to select migrant and non-migrant households from each of the selected EAs. The migrant households were further stratified into three groups: seasonal migrants, return migrants and absent out-migrants. A total of 15 households were purposively selected from each EA, consisting of 4 households from the non-migrant households and 11 households from the migrant households. The final stage was the purposive selection of an adult household member, irrespective of gender and who has more knowledge about the household for interview.

\section{Conceptual Framework and Econometric Procedure}

The main focus of this study is to assess the determinants of internal migration which hinges on a number of models of migration. Unlike the earlier models of migration that analyze the individual's decision to move as a function of his/her own expected net economic benefit (Sjasstad 1962; Todaro 1965), a growing literature has been modelling migration as both an individual and family decision that not only maximizes income but also minimizes risks (Stark, 1991; Stark \& Bloom 1985; Taylor 2001). Most family decision migration models thus imply that while a member of the household migrates, the rest of the household which remains at the origin is focused on maintaining itself and keeping ties with the migrant as an economic and social unit. To explain this type of behaviour of family decision towards migration, models typically include variables such as: physical and human capital assets, including household demographic composition and information on adults' education, which can be proxies for risk aversion and access to credit; stochastic variables to measure the type of risks that the household copes with; and family networks at destination, included as a form of social capital, that together with the human capital assets can generate differences in the net benefit of the migration decision across households (Ritcher \& Taylor 2007). Following this conceptual framework, I modelled the decision to migrate internally as a function of individual characteristics, household and community characteristics. Specifically, the model is specified as follows:

Where $\mathrm{M}_{\mathrm{i}}$ is the probability that individual $\mathrm{i}$ will migrate

$\mathrm{X}_{1}-\mathrm{X}_{3}$ is the individual, household and community characteristics respectively.

Equation 1 is a discrete choice model which would be estimated using the maximum likelihood approach to assess the determinants of internal migration as the second objective seeks to do. 


\section{Results and Discussions}

\section{Socio-economic Characteristics of Migrants and Non-migrants}

Migration as indicated earlier is motivated by certain characteristics of the individual, the household and the community. The examination of these characteristics is relevant to the extent that it guide the household to understand who can/should migrate, how and where to migrate to. In the light of these, the current study examined the socio-economic characteristics of both migrant and non-migrants as indicated in my first objective.

The socioeconomic characteristics of members of the 315 households selected and interviewed comprising 228 absent/current migrants, 72 returned migrants and 2,199 non-migrants were examined with respect to age, sex, highest level of education attained, marital status, regions/districts of origin and destination as well as reasons for migration.

The average household size of the study area was eight, twice the national average of 4 (GLSS 5) with 69.48 percent of non-migrant households having members more than this average compared to 65 percent of migrant households. Only a small percentage of both migrant and non-migrant households have household size of at most four members (6.67 and 5.87 percent respectively).

A higher percentage of migrants, both absent and returned are in the age group of 21-30 years with 14.12 percent of the absent migrants aged less than 18 years (see Table 1 ), suggesting that there were not many young migrants involved in current internal migration.

Table 1: Distribution of migrants by age and sex

\begin{tabular}{|l|l|l|l|l|l|l|}
\hline \multirow{2}{*}{ Age } & \multicolumn{2}{|l}{ Absent Migrants } & \multicolumn{2}{l|}{ Returned Migrants } \\
\cline { 2 - 7 } & Males (\%) & Females (\%) & Total (\%) & Males (\%) & Females (\%) & Total (\%) \\
\hline O-10 & 0.70 & 4.71 & 2.19 & 0.00 & 0.00 & 0.00 \\
\hline $11-20$ & 20.98 & 28.24 & 23.68 & 20.69 & 18.60 & 19.44 \\
\hline $21-30$ & 37.76 & 40.00 & 38.60 & 48.28 & 48.84 & 48.61 \\
\hline $31-40$ & 26.57 & 21.18 & 24.56 & 24.14 & 23.26 & 23.61 \\
\hline $41-50$ & 10.49 & 3.53 & 7.89 & 3.45 & 6.98 & 5.56 \\
\hline $51-60$ & 2.10 & 1.18 & 1.75 & 3.45 & 2.33 & 2.78 \\
\hline $60+$ & 1.40 & 1.18 & 1.32 & 0.00 & 0.00 & 0.00 \\
\hline Total (\%) & 100.00 & 100.00 & 100.00 & 100.00 & 100.00 & 100 \\
\hline N & 143.00 & 85.00 & 228.00 & 29.00 & 43.00 & 72.00 \\
\hline & & $<18=3.5 \%$ & $=14.12 \%$ & & $<18=4.65 \%$ & \\
\hline
\end{tabular}

Source: Author's construct from MOP survey, 2013 
Regarding the relationship between migrants and their household heads, it is observed that more than half (52.20 percent) of these migrants were either children or adopted children to the household head in which they hailed from. This corroborate the findings of Pickbourn (2011) who remarked that most female migrants in the Savelugu-Nantong district in the Northern Region of Ghana were either the daughters to the household heads or fosterdaughters of the head's wife. The larger proportion of children migrating instead of the heads or their spouses could be explained perhaps by the fact that they are single and the cost of migrating is minimal relative to that of their parents. Children also used migration as a way of acquiring material things such as cooking utensils and clothing in preparation for their future marriage. A small percentage (7 percent) of the migrants is spouses to the household heads.

In terms of sex distribution and region of destination, the result indicate that a higher percentage of female than male current migrants migrate to Greater Accra than to Ashanti Region (see Table 2). Furthermore, a higher proportion of males are involved in intra-regional migration than their female counterparts (32.09 and 25.32 percent respectively). The domination of males in intra-regional migration could be explained by the fact that males with primary or no education are involved in rural-rural migration seasonally to sell their labour and return to the community when it's time for farming. This finding contradicts some earlier findings which suggest that males dominate in long distance migration and females in shorter distance ones (Manning Patrick, 2005 \& Ranga Dick, 2004).

Table 1: Distribution of migrants by regions of destination and by sex

\begin{tabular}{|l|l|l|l|l|l|l|}
\hline \multirow{2}{*}{ Region } & \multicolumn{4}{|l}{ Absent Migrants } & \multicolumn{2}{l}{ Returned Migrants } \\
\cline { 2 - 6 } & Males (\%) & Females (\%) & Total (\%) & Males (\%) & Females (\%) & Total (\%) \\
\hline G. Accra & 29.10 & 41.77 & 33.83 & 44.00 & 60.00 & 53.56 \\
\hline Ashanti & 22.39 & 26.58 & 23.95 & 12.00 & 30.00 & 22.75 \\
\hline Northern & 32.09 & 25.32 & 29.56 & 24.00 & 7.50 & 14.15 \\
\hline B.Ahafo & 9.70 & 1.27 & 6.56 & 12.00 & 2.50 & 6.33 \\
\hline Western & 0.75 & 2.53 & 1.41 & 4.00 & 0.00 & 1.61 \\
\hline Eastern & 0.75 & 1.27 & 0.94 & 4.00 & 0.00 & 1.61 \\
\hline Central & 0.75 & 0.00 & 0.47 & 0.00 & 0.00 & 0.00 \\
\hline U/East & 4.48 & 1.27 & 3.28 & 0.00 & 0.00 & 0.00 \\
\hline U/West & 0.00 & 0.00 & 0.00 & 0.00 & 0.00 & 0.00 \\
\hline Total (\%) & 100.00 & 100.00 & 100.00 & 100.00 & 100.00 & 100.00 \\
\hline
\end{tabular}

Source: Author's calculation from the MOP survey, 2013

What is interesting is the finding that, inter regional migration is gradually being internalised as more migrants migrate within the Northern region than the four southern regions combined aside Greater Accra and Ashanti regions. Consistent with existing evidence 
(Caldwell, 1968 and Ackah \& Medvedev, 2010), migrants are much more likely to be male: the male-to-female ratio for migrants 18 years or more is 1.16 compared to 0.91 for nonmigrants. However, the proportion of female migrants decreases faster than male migrants in older age groups, suggesting that more males tend to migrate at older ages than females. This might be attributed to females getting married as they grow older, for which reason they need to stay and take care of the family. Also in some cultures of the source districts, a woman migrating at old age is seen as an irresponsible one as she is seen not prepared to shoulder any responsibility/challenges emanating from her marital home. As in Pickbourn's (2011) study, most women in the Savelugu district of the Northern region are provided with only maize/grains to prepare meals for their households. Taking a cue from this finding means that it is the women who have to get other ingredients from their own resources to prepare the meals. Unknowingly, a woman migrating at old age might be seen to be avoiding these responsibilities.

There are empirical observations also, which is compatible with the human capital model that the rate of migration decreases with age (Sjaastad, 1962). In the study, the rate of migration increases with age and tend to decrease after 30 years. This could be explained by the fact that between 15 and 30 years, most people might still be single and not saddled with any household responsibility and therefore can afford to migrate. Beyond the age of 30 years, most people will now be married and are given household responsibilities and that might therefore reduce their probability to migrate. At this age the cost of migrating (psychic cost) is quite huge, making migration a disincentive.

By districts of origin of absent migrants, about one - fifth of the absent migrants came from the Tolon District, which is the largest producer of migrants in the study area (see Table 3). Tamale Metropolis reported no absent migrant. This contradicts findings by Kwankye et al. (2009) where Tamale was cited as dominant district of origin by child migrants. The Tolon District had the largest female out-migrants than other districts in the study area, though produces more male than female migrants from the district. Yendi Municipality, West Mamprusi and Central Gonja districts also recorded higher outmigration rates with 14.47, 11.84 and 11.84 percent respectively of current migrants coming from these districts. 
Table 3: Distribution of migrants by district of origin and sex

\begin{tabular}{|l|l|l|l|l|l|l|}
\hline \multirow{2}{*}{ District } & \multicolumn{2}{|l}{ Absent Migrants } & \multicolumn{2}{l}{ Returned Migrants } \\
\cline { 2 - 7 } & Males (\%) & Females (\%) & Total (\%) & Males (\%) & Females (\%) & Total (\%) \\
\hline Sagnarigu & 5.59 & 4.71 & 5.26 & 0.00 & 0.00 & 0.00 \\
\hline Kumbungu & 7.69 & 10.59 & 8.77 & 3.45 & 2.33 & 2.78 \\
\hline East Gonja & 9.09 & 3.53 & 7.02 & 0.00 & 4.65 & 2.78 \\
\hline East Mampurisi & 6.99 & 5.88 & 6.58 & 10.34 & 13.95 & 12.50 \\
\hline Central Gonja & 8.39 & 17.65 & 11.84 & 13.79 & 2.33 & 6.94 \\
\hline Karaga & 4.20 & 4.71 & 4.39 & 0.00 & 11.63 & 6.94 \\
\hline Savelugu & 11.19 & 9.41 & 10.53 & 17.24 & 23.26 & 20.83 \\
\hline Tamale Metro & 0.00 & 0.00 & 0.00 & 0.00 & 0.00 & 0.00 \\
\hline Tolon & 19.58 & 18.82 & 19.30 & 20.69 & 18.60 & 19.44 \\
\hline West Mampurisi & 11.19 & 12.94 & 11.84 & 27.59 & 18.60 & 22.22 \\
\hline Yendi & 16.08 & 11.76 & 14.47 & 6.90 & 4.65 & 5.56 \\
\hline Total & 100.00 & 100.00 & 100.00 & 100.00 & 100.00 & 100.00 \\
\hline N & 143 & 85 & 228 & 29 & 43 & 72 \\
\hline
\end{tabular}

Source: Author's calculation from the MOP survey, 2013

Unlike Tolon and Yendi districts where male out-migrants out-numbered their female counterparts, the Central Gonja district recorded higher percentage of female out-migrants than their male counterparts.

The distribution of migrants by marital status shows that more than half (50.21 percent) of current migrants are single (see Table 4). On the contrary, a higher percentage of return migrants are married. For those who are married, a higher proportion (47.10 percent) of male migrants are married compared with 44.44 percent of female migrants reported married. This suggests that marriage is a barrier for potential female migrants. This could be attributed to the fact that those that are married might have found it difficult to move without their households, unlike the single ones who can move at any time when the need arises, most especially when searching for employment. This finding is consistent with the migration literature which indicates that most migrants are young and single (Ehirim et al, 2012). 
Table 4: Marital status by sex and migration status

\begin{tabular}{|l|l|l|l|l|l|l|}
\hline \multirow{2}{*}{ Sex } & \multicolumn{2}{|l}{ Absent Migrants } & \multicolumn{2}{l}{ Return Migrants } \\
\cline { 2 - 7 } & Males (\%) & Females (\%) & Total (\%) & Males (\%) & Females (\%) & Total (\%) \\
\hline Single & 52.90 & 45.68 & 50.21 & 58.62 & 27.91 & 40.28 \\
\hline Married & 47.10 & 44.44 & 46.11 & 41.38 & 62.79 & 54.17 \\
\hline Living with partner & 0.00 & 1.23 & 0.46 & 0.00 & 0.00 & 0.00 \\
\hline Separated & 0.00 & 1.23 & 0.46 & 0.00 & 2.33 & 1.39 \\
\hline Divorced & 0.00 & 6.17 & 2.30 & 0.00 & 2.33 & 1.39 \\
\hline Widowed & 0.00 & 1.23 & 0.46 & 0.00 & 4.65 & 2.78 \\
\hline Total (\%) & 100.00 & 100.00 & 100.00 & 100.00 & 100.00 & 100.00 \\
\hline N & 143 & 85 & 228 & 29 & 43 & 72 \\
\hline
\end{tabular}

Source: Authors calculation from MOP survey, 2013

The results of the data analysis further revealed that a household with at least two members is likely to produce an absent migrant. The number of migrants increases as the household size increases. This can be explained by the fact that as the number of people in a household increases, the household can afford to ask some of its members (surplus labour) to undertake migration so as to mitigate the household consumption risk as espoused by the New Economics of Labour Migration (NELM) theory. Other studies such as Huy's (2009); Mariapia's (2008); Hossain's (2001) and Alan et al. (1999) indicate that migration decision of households is positively associated with household size.

In terms of migration and educational status, the study noted that a little over half of the current migrants (50.37 percent) have primary or no education (see Table 5). This figure increases for returned and non-migrants (58 and 61.57 percent respectively). This finding is at variance with Sjaadstad's (1962) proposition that migrants are young and more educated. 
Table 5: Highest educational qualification by sex and migration status

\begin{tabular}{|c|c|c|c|c|c|c|c|}
\hline \multirow{2}{*}{ Educational Level } & \multicolumn{3}{|c|}{ Absent Migrants } & \multicolumn{3}{|c|}{ Returned Migrants } & \multirow{2}{*}{$\begin{array}{l}\text { Non-Migrants } \\
\text { Total }\end{array}$} \\
\hline & Males & Females & Total & Males & Females & Total & \\
\hline None & 24.17 & 48.33 & 33.18 & 26.09 & 62.96 & 46.00 & 34.70 \\
\hline Primary & 12.50 & 16.67 & 14.05 & 8.70 & 11.11 & 10.00 & 23.93 \\
\hline Middle & - & - & - & $4 \cdot 35$ & - & 2.00 & 0.86 \\
\hline JSS/JHS & $17 \cdot 50$ & 8.33 & 14.08 & 26.09 & 7.41 & 16.00 & 14.75 \\
\hline Comm'cial / Voc. & - & 1.67 & 0.62 & - & - & - & 0.06 \\
\hline O’Level & - & - & - & - & - & - & 0.31 \\
\hline SSS/SHS & 25.00 & 11.67 & 20.03 & 8.70 & 7.41 & 8.00 & 11.93 \\
\hline Training College & 4.17 & $3 \cdot 33$ & 3.86 & - & - & - & 1.47 \\
\hline Prof./Tech & - & 3.33 & 1.24 & 8.70 & - & 4.00 & 0.31 \\
\hline Tertiary & 8.33 & 1.67 & 5.85 & 13.04 & - & 6.00 & 3.00 \\
\hline Koranic & 5.00 & - & 3.14 & $4 \cdot 35$ & - & 2.00 & 2.94 \\
\hline A'Levels & - & - & - & - & - & - & 0.06 \\
\hline Others & - & - & - & - & - & - & 0.49 \\
\hline Don't know & $3 \cdot 33$ & 5.00 & 3.95 & - & 11.11 & 6.00 & 5.20 \\
\hline Total (\%) & 100.00 & 100.00 & 100.00 & 100.00 & 100.00 & 100.00 & 100.00 \\
\hline $\mathrm{N}$ & 143 & 85 & 228 & 29 & 43 & 72 & 2199 \\
\hline
\end{tabular}

Source: Author's calculation from MOP survey, 2013

By sex and migration status, the percentage of female returned migrants (74.07 percent) is higher than female absent migrants (65 percent) with primary or no education. This fall in the number of migrants with primary or no education can be attributed to perhaps public education of parents and motivation by government (school feeding program and capitation grants) and Non-Governmental Organisations (NGOs) in the study area to send their wards to school, most especially the girl child. This is corroborated by the publication of Ghana News Agency (GNA), 28th February, 2009 captioned "NGO donate bicycles to school girls", all as an attempt to motivate the girls to go to school. Other NGOs such as the World Vision, School for Life and Ibis all support this call of making education more accessible and acceptable to the less privilege. Among the current migrants however, there were more females (65 percent) than males (41.67 percent) with primary or no education.

Aside no education, a larger proportion (20.03 percent) of current migrants have completed SSS with less than a tenth (9.71 percent) having tertiary qualifications. Among those who completed the SSS, males recorded a higher percentage than females (25 and 11.67 percent 
respectively). The same can be said about tertiary qualifications. This huge difference in qualifications between sex could be explained perhaps by the ancient beliefs in the region (which still exist anyway) that the female child is for the kitchen and does not need education beyond the primary level. What is counter intuitive, though is the finding that more educated migrants ( 35.71 percent) migrate within the source region (intra-regional migration) compared to 21.43 percent each to Greater Accra and Ashanti regions. This contradict other studies elsewhere, especially among scholars of the human capital theory of migration (Sjaastad, 1962) and the efficiency hypothesis theory (Courchene, 1970 and Schwartz, 1973), who argued that migrants are self-selected and that selection decisions are related to migrant quality outcomes such as education and with the more educated people undertaking longer distance migration (Tsegai \& Plotnikova, 2004; Dustmann \& Glitz, 2011). This could be perhaps due to their greater access to information and a possible breakthrough of any language differences (minimum cost of migration).

\section{Determinants of Internal Migration}

There are multiple reasons or drivers of people migrating in Ghana - economic, social and political reasons. It is worthwhile to ascertain the main drivers of migration in the region, given that the northern region is characterised by high incidence of poverty and out-migration rates (GSS, 2013). Giving reasons for which current and returned migrants undertake migration, most migrants give economic reasons for migrating. For example, the result of the data analysis revealed that majority of both current and returned migrants (62.44 and 79.10 percent respectively) cited job/employment as the most important reason for migrating (see Table 6). This result is expected and can be attributed to limited job or employment opportunities in the districts of origin, especially in the dry season. 
Table 6: Reasons for migrating by migration status and sex

\begin{tabular}{|c|c|c|c|c|c|c|}
\hline \multirow{2}{*}{ Reason } & \multicolumn{3}{|c|}{ Absent Migrants } & \multicolumn{3}{|c|}{ Returned Migrants } \\
\hline & Males & Females & Total & Males & Females & Total \\
\hline Job transfer/opportunity & 10.37 & 5.13 & 8.45 & 19.23 & 4.88 & 10.45 \\
\hline Seek work/better job & 60.00 & 66.67 & 62.44 & 61.54 & 90.24 & 79.10 \\
\hline Study training & $15 \cdot 56$ & 11.54 & 14.08 & $15 \cdot 38$ & 0.00 & $5 \cdot 97$ \\
\hline To get married & 0.74 & 6.41 & 2.82 & 0.00 & 0.00 & 0.00 \\
\hline To accompany family & 1.48 & 0.00 & 0.94 & 3.85 & 4.88 & 4.48 \\
\hline To join family & 1.48 & 7.69 & 3.76 & 0.00 & 0.00 & 0.00 \\
\hline Declining yields in agriculture & $5 \cdot 93$ & 2.56 & 4.69 & 0.00 & 0.00 & 0.00 \\
\hline Civil conflict/war & 0.74 & 0.00 & 0.47 & 0.00 & 0.00 & 0.00 \\
\hline Drought & 2.22 & 0.00 & 1.41 & 0.00 & 0.00 & 0.00 \\
\hline To join friends & 0.74 & 0.00 & 0.47 & 0.00 & 0.00 & 0.00 \\
\hline Others & 0.74 & 0.00 & 0.47 & 0.00 & 0.00 & 0.00 \\
\hline Total & 100.00 & 100.00 & 100.00 & 100.00 & 100.00 & 100.00 \\
\hline $\mathrm{N}$ & 143 & 85 & 228 & 29 & 43 & 72 \\
\hline
\end{tabular}

Source: Authors calculation from MOP survey, 2013

With respect to sex, a higher percentage of females than males cited job opportunities as the major reason for migrating regardless of their migration status. This finding is at odds with the findings of Castaldo et al. (2012) that most women in Ghana and India migrate for marriage reasons than males. However, more female returned migrants (90.24 percent) than current female migrants (66.67 percent) migrate to look for jobs with no significant difference between male current (6o percent) and returned migrants (61.54 percent). Other major reasons cited are studying or training and job transfer. Almost the same proportion of current and returned male migrants stated education as the reason for migration with lower percentage of females (11.54 percent) than males (15.56 percent) among current migrants moving for the same reason.

It was also noted that for those who migrated to seek jobs, majority of them (68.42 percent) choose Greater Accra and Ashanti as their regions of destination with higher percentage of migrants (40.6o percent) moving to Accra than Kumasi. This could be explained by the perceived jobs availability in the south and more so in Accra than Kumasi. Perhaps, Accra being the national capital may be considered as having better job opportunities than Kumasi. There has been forced migration in the north, though it is the least among the reasons given for migrating. In all, 0.47 percent of the migrants migrated because of civil conflict with only males involved. This could be attributed to the pockets of chieftaincy disputes in the region where men mostly are involved. 
Having assessed the socio-demographic characteristics of the studied population and the main drivers of migration, it would be insightful to examine the determinants of an individual probability to migrate as the second objective seeks to achieve. The maximum likelihood probit estimates and their marginal values of estimating equation 1 are presented in Table 7. Before discussing the parameter estimates, one general observation is worth noting. The likelihood ratio chi-squared statistic, testing the null hypothesis that all regressors are jointly zero, is strongly rejected. The estimation results show that the parameter estimates generally conform to the a priori expectations. The probability of migrating is statistically dependent on individual sex, age, sex of household head, household size and access to at least one community facility².

Consistent with prior expectation and existing literature, the probability of migration increases with age. Age provides a rough proxy for work experience and as such, it gives some indication of the earning potential of the individual and the ability to finance the cost of migration. A quadratic term of age is included in the formulation to cater for diminishing returns to experience. The coefficient of age is positive and negative for square of age and both are statistically significant. Education of individuals shows the expected sign though not significant. This could be interpreted to mean that the probability to migrate increases with increase in individual educational level.

Table 7: Determinants of an individual's likelihood to be an internal migrant

\begin{tabular}{|c|c|c|c|c|}
\hline \multirow{2}{*}{ Variable } & \multirow{2}{*}{ Mean } & \multirow{2}{*}{ Std. Dev } & \multicolumn{2}{|l|}{ Probit Results } \\
\hline & & & Coefficient & Marginals (dy/dx) \\
\hline Intercept & - & - & $-2.95(-7.22)^{* * *}$ & - \\
\hline Sexindiv & 0.51 & 0.50 & $-0.21(-2.42)^{* *}$ & $-0.26(-2.45)^{* *}$ \\
\hline Ageindiv & $25 \cdot 57$ & 17.74 & $0.19(10.38)^{* * *}$ & $0.24(10.38)^{* * *}$ \\
\hline Agesqur & 968.05 & $1244 \cdot 32$ & $-0.003(-9.85)^{* * *}$ & $-0.0004(-9.85)^{* * *}$ \\
\hline Educindiv & 11.84 & 20.79 & $0.0007(0.31)$ & $0.0001(0.31)$ \\
\hline Sexheadhh & 0.90 & 0.30 & $0.28(1.66)^{*}$ & $0.03(1.66)^{*}$ \\
\hline Marheadhh & 2.27 & 1.00 & $0.01(0.29)$ & $0.0017(0.29)$ \\
\hline Hsehdsize & $9 \cdot 97$ & 3.74 & $-0.02(-2.01)^{* *}$ & $-0.0030(-2.01)^{* *}$ \\
\hline Hseownship & 0.94 & 0.25 & $-0.24(-1.20)$ & $-0.03(-1.20)$ \\
\hline Comtyfacil & 1.91 & 1.02 & $-0.18(-3.66)^{* * *}$ & $-0.02(-3.66)^{* * *}$ \\
\hline $\mathrm{N}$ & \multicolumn{4}{|l|}{1732} \\
\hline Pseudo R2 & \multicolumn{4}{|l|}{0.17} \\
\hline Prob > Chi2 & \multicolumn{4}{|l|}{0.00} \\
\hline Log Likelihood & \multicolumn{4}{|l|}{-539.12} \\
\hline
\end{tabular}

Note: The $\mathrm{z}$-statistics are in parenthesis and ${ }^{* * *},{ }^{* *}$ and ${ }^{*}$ implies the level of significance at $1 \%, 5 \%$ and $10 \%$ respectively.

Source: Author's estimation from the MOP dataset.

2 Electricity, Natural gas, Safe drinking water, Sewage system, Garbage collection and Telephone. 
Somehow at odd with the literature, which found that females are tied movers than males (Banerjee \& Phan, 2010), the current estimate indicates that males are less likely to migrate than females as indicated by the sexindiv variable. This finding corroborates Katz's (2000) but contradict the results of the earlier descriptive analysis which indicate that males dominate in current internal migration from the northern region than females. This increase in the participation of females in migration is perhaps due to changes in gender roles at the study area and the possible effect of networks in favour of females than males. Sex of head of households (sexheadhh) coefficient is positive and significant, an indication that migrants are more likely to come from households with male heads. That is, households headed by males are 3.5 percent more likely to produce a migrant than female-headed households. This finding is at odds with Ackah \& Medvedev (2010) finding which suggest that individuals are more likely to migrate if the head of their household is female. The possible explanation may be that male - headed households have more resources/assets than female-headed households as shown in the literature and therefore can support a member financially to undertake migration. Male heads prefer sharing of responsibilities and therefore would want everybody in the household contribute their quota to the upkeep of the home, a situation that can ignite/ encourage migration.

Household size negatively and significantly affect the decision to migrate, an indication that larger household size are less likely to produce migrants contrary to other studies (Tsegai, 2007 and Stark et al, 1997) who argued that migration increases with house size. The negative coefficient of the house size variable can have two interpretations. Firstly, it could be that larger households may want to play the 'free rider game' where every other member looks up to the next to act in the best interest of all and therefore lacks the propensity to migrate ${ }^{3}$. Secondly and the most likely manner, it is always difficult for such households to arrive at consensus on the decision to produce a migrant.

The community facility variable (comtyfacil) is negative and significant. Access to community facility in the specification of the model was to capture the pull factors of migration. And as expected, the decision to migrate decreases as a household increases it access to the public facilities. That is, households with access to public facilities are 2.2 percent less likely to produce a migrant. This is consistent to the findings by Ackah \& Medvedev (2010) who, using the GLSS 5 data concluded that, communities having access to better drinking water and sanitation and subsidized health care are less likely to produce migrants. Though not significant, the house ownership variable was rightly signed, meaning that households owning their houses are less likely to produce migrants. An assessment of the effect of child dependency on the decision to migrate was made, though no meaningful result was produced using the probit.

Migration networks have been found to be a key determinant in the probability to migrate and consistently are the most important single factor that may influence future migration (Tsegai, 2007; Richter \& Taylor, 2006; Tutu, 1995 and Caldwell, 1976). How then did having a

3 In the case of economic migrants. 
network/contact person at destination before migration influence the decision of people to migrate in the study area?

Analysis of the data revealed that more than one-half of current migrants have contact persons (migration network) before migrating compared to only 37.31 percent for returned migrants (see Table 8). A possible explanation may be that current migrants have more known faces at destination than returned migrants. The advent and widespread use of mobile phones in the area make it easier for one to talk to a friend or relative at destination and which has the tendency of promoting migration.

Table 8: Distribution of migrants by network status before migration and by sex

\begin{tabular}{|l|l|l|l|l|l|l|}
\hline \multirow{2}{*}{ Response } & \multicolumn{2}{|l|}{ Absent Migrant } & \multicolumn{2}{l|}{ Returned Migrant } \\
\cline { 2 - 8 } & Male & Female & Total & Male & Female & Total \\
\hline Have contact before migration & 49.26 & 55.70 & 51.63 & 38.46 & 36.59 & 37.31 \\
\hline Have no contact before migration & 50.74 & 44.30 & 48.37 & 61.54 & 63.41 & 62.69 \\
\hline Total (\%) & 100 & 100 & 100 & 100 & 100 & 100 \\
\hline N & 143 & 85 & 228 & 29 & 43 & 72 \\
\hline
\end{tabular}

Source: Authors construct from MOP survey, 2013.

By sex, there are more female (55.70 percent) than male (49.26 percent) current migrants with networks before migrating. The reverse is true for return migrants as more males than females reported having migration networks before migrating (38.5 and 36.6 percent respectively). The high number of males with networks before migrating could be attributed to the fact that, males were the dominant groups undertaking migration in the area until recently (Pickbourn, 2011) and therefore could have more networks at destinations than their female counterparts. These results are expected as the effects of networks are gender specific (Richter \& Taylor, 2006). If networks' duty, for example, is provision of job information, and if males and females are concentrated in different sectors of the destination economy, then networks with male migrants may have little effect on female migration, and vice versa.

\section{Conclusions and Recommendations}

Migrants from the Northern Region of Ghana were not very young. They were either children or adopted children of heads of households they lived in before migrating and were mostly females. The majority of the migrants were more likely to come from Tolon district given that close to 20 percent of absent migrants were from this district. Most migrants were single and had little or no education, an indication of negative selectivity of migrants. The more educated migrants undertake intra-regional migration contrary to previous literature 
that argued that the more educated undertake longer distance migration. This finding suggests that the human capital theory does not explain migration in the study area.

The main reason cited for migrating from the Northern Region is economic. Furthermore, migrants are more likely to come from households with male heads. Similarly, access to community facilities (electricity, pipe-born water) reduces the likelihood of households producing migrants. Migrant networks were also found to be a key facilitating element in the migration of people from the study area. In light of this, one can conclude that the network theory explains migration in the Northern Region because the decision to travel to a large extent depends on the availability of friends or relations (networks) in the destination area.

It would be useful for government and other Non-Governmental Organisations (NGOs) considering policies to streamlining migration to give more priority to education in terms of access and affordability. This comes from the backdrop that the majority of the migrants from the study area to other regions were people with little or no education with the more educated involved in intra-regional migration. Government and other stakeholders such as the private sector and NGOs should consider providing job opportunities ${ }^{4}$ and extending access to public facilities such as schools, electricity, health posts and portable drinking water to the people.

\section{References}

Ackah, c. and Medvedev, D. (2010). Internal migration in Ghana: determinants and welfare Impacts. World Bank 2010 Ghana poverty assessment paper.

Alan de Brauw, J. Edward Taylor, and Scott Rozelle (1999). The impact of migration and remittances on rural incomes in China. Paper submitted for 1999 American Agricultural Economics Association annual meetings Nashville, August 8-11, 1999.

Banerjee, R. and Phan, M. (2010). Do tied movers get tied down? The occupational displacement of dependent applicant immigrants in Canada. CERIS final report.

Boakye-Yiadom, L. and McKay, A. (2006). Migration between Ghana's rural and urban areas: The impact on migrants' welfare. Available: http://www.pegnet.ifw- kiel.de/papers/ conference-2007.

Caldwell, J.C. (1968). Determinants of rural-urban migration in Ghana, population studies: A Journal of Demography, 22(3), pp. 361-377.

Castaldo, A., Deshingkar, P. and McKay, A. (2012). Migrating out of poverty. Research programme consortium. University of Sussex working paper 7.

4 Majority of migrants cited seeking jobs/employment opportunities as reasons for their migration. 
Courchene, T. J. (1970). Interprovincial migration and economic adjustment, Canadian Journal of Economics 3, 550-76.

Dustmann, C. and Glitz, A. (2011). Migration and education. NORFACE migration discussion paper No. 2011-11. Available at www.norface-migration.org.

Ehirim, NC, Onyeneke, RU., Chidiebere-Mark, NM. and Nna-buihe, vC (2012). Effects and prospect of rural to urban migration on the poverty status of migrants in Abia State, Nigeria. Agricultural Science Research Journal, 2(4): 147-149.

Ghana Statistical Service (2012). 2010 population and housing census summary report, Accra, Ghana.

Hossain, M.Z (2001). Rural-urban migration in Bangladesh: A micro-level study paper presented in a poster session on internal migration at the Brazil IUSSP conference during August 20-24.

Huynh Truong Huy (2009). Rural to urban migration as a household decision: Experimental evidences from the Mekong delta, Vietnam. DEPOCEN working paper series No. 2009/17.

Katz, Elizabeth (2000). Individual, household and community-level determinants of migration in Ecuador: Are there gender difference? A paper prepared for annual meeting of the population association of America Los Angeles, CA, March 23-25.

Kwankye, S. O., J. K. Anarfi, C. A. Tagoe and A. Castaldo (2007). Coping strategies of independent child migrants from northern Ghana to southern cities. Working paper, T-23. Brighton: development research centre on migration, globalisation, and poverty, University of Sussex.

Litchfield, J. and H. Waddington (2003). Migration and poverty in Ghana: evidence from the Ghana Living Standards Survey, Sussex migration working paper no. 10. Sussex centre for migration research. London: MacMillan Press Ltd.

Manning, P. (2005). Migration in world history. New York: Routledge.

Mariapia, M. (2008). Migration and technological change in rural households: complements or substitutes?, Journal of Development Economics, 85, pp. 150-175.

Pickbourn, L. J (2011). Migration, remittances and intra-household allocation in northern Ghana: Does gender matter? PhD dissertation, submitted to the University of Massachusetts Amherst.

Ranga, D. (2004).The migration effects of the economic structural adjustment programme on a rural community in Zimbabwe. University of Zimbabwe. Available online at http://www. bioline.org.br/pdf?epo4oog. 
Richter, s. and Taylor, J. E. (2006). Gender and the determinants of international migration from rural Mexico over time. University of California, Davis.

Stark, O. and Bloom, D. (1985). The new economics of labor migration, American Economic Review, 75, pp. 173-178

Sjaastad, A. Larry (1962). The costs and returns of human migration. The Journal of Political Economy 70: 80-93.

Tsegai, D., Plotnikova, M. (2004). Migration and household income differentials in the volta basin of Ghana: A sample selection approach. Paper presented at Canadian economics association 38 th annual meetings, June.

Tsegai Daniel (2007). Migration as a household decision: What are the roles of income differences? Insights from the Volta Basin of Ghana. The European Journal of Development Research, Vol.19, No.2, June 2007, pp.305-326.

UNDP (2009). Overcoming barriers: human mobility and development. Human Development Report 2009, UNDP, New York. 